\title{
ANALISIS MULTIMODAL REPRESENTASI MAHASISWA CALON GURU PADA PEMAHAMAN KONSEP LISTRIK DINAMIS
}

\author{
Adolfina Galla, I Komang Werdhiana dan Syamsu \\ gallaadolfina@gmail.com \\ Program Studi Pendidikan Fisika FKIP Universitas Tadulako \\ Jl. Soekarno Hatta Km. 9 Kampus Bumi Tadulako Tondo Palu - Sulawesi Tengah
}

\begin{abstract}
Penelitian ini bertujuan mengetahui multimodal representasi mahasiswa calon guru fisika pada pemahaman konsep listrik dinamis. Penelitian ini merupakan penelitian deskriptif-kualitatif dengan desain studi kasus. Subjek penelitian berjumlah 24 orang yang dipilih dengan menggunakan teknik purposive sampling. Data diperoleh melalui tes pilihan ganda beralasan yang berjumlah 18 butir soal dengan menggunakan representasi visual, matematis, dan verbal. Berdasarkan hasil pengolahan data hasil penelitian, diperoleh persentase skor kemampuan representasi visual dengan jawaban yang disertai alasan sebesar $34,17 \%$ dan yang tidak disertai alasan sebesar $17,50 \%$. Persentase skor kemampuan representasi matematis untuk jawaban benar disertai alasan sebesar 22,50\% dan yang tidak disertai alasan sebesar $10,00 \%$. Persentase skor kemampuan representasi untuk jawaban benar disertai alasan sebesar $14,58 \%$ dan yang tidak disertai alasan sebesar $8,33 \%$. Hasil wawancara dengan responden diperoleh bahwa representasi visual lebih dipahami oleh responden karena dianggap mudah dianalisa. Sedangkan representasi matematis dianggap sukar karena membutuhkan analisis perhitungan. Sedangkan untuk representasi verbal dianggap membutuhkan analisis yang tinggi.
\end{abstract}

Kata kunci: multimodal representasi, calon guru, listrik dinamis.

\section{PENDAHULUAN}

Pelaksanaan kurikulum didasarkan pada potensi, perkembangan dan kondisi peserta didik untuk menguasai kompetensi yang berguna bagi dirinya ${ }^{[1]}$. Dalam Kurikulum Tingkat Satuan Pendidikan, fisika merupakan mata pelajaran yang lebih banyak memerlukan pemahaman. Agar penguasaan standar kompetensi dalam suatu pembelajaran dapat tercapai maka mahasiswa sebagai calon guru harus dapat memahami konsep-konsep setiap materi yang akan diajarkan.

Banyak beranggapan bahwa fisika merupakan pelajaran yang sulit. Salah satu alasan fisika dikatakan pelajaran yang sulit karena fisika menuntut siswa untuk menguasai representasi-representasi berbeda untuk mengembangkan pengetahuan tentang konsepkonsep ilmiah. Pembelajaran fisika juga dominan ke representasi matematis dimana pemahaman konsepnya kurang diperhatikan. Kesulitan tersebut dapat terjadi karena karakteristik materi pembelajaran fisika yang abstrak, rumit, atau asing, serta menuntut kemampuan untuk menguasai dan mengelola perubahan diantara representasi-representasi yang berbeda.

Penggunaan representasi pada fisika dapat dilakukan dalam dua bentuk, yaitu dalam proses belajar mengajar dan dalam proses evaluasi. Dalam proses evaluasi dapat digunakan tes yang tujuannya untuk mengetahui kemampuan memecahkan masalah. Agar siswa dapat mengemukakan pendapatnya secara rinci.

Waldrip (2014) menyatakan bahwa pemberian soal-soal latihan atau ujian dan tugas yang tergolong sulit dapat meningkatkan kemampuan representasi siswa, karena dalam soal yang tergolong sulit tersebut siswa dituntut untuk mengerahkan semua kemampuan yang dimilikinya sehingga siswa dapat menyelesaikan soal-soal fisika dengan sukses dan hasil belajar siswa dapat mengalami peningkatan ${ }^{[2]}$. Wanhar (dalam Pertiwi, 2013) menyatakan bahwa penyelesaian soal-soal fisika penting untuk menuntun siswa seperti pengetahuan yang abstrak. Semakin mengerti pengetahuan yang abstrak dan keterkaitannya, siswa akan mampu berpikir dan menyelesaikan soal-soal fisika dalam waktu yang relatif singkat ${ }^{[3]}$. 
Berdasarkan masalah di atas, diperlukan suatu cara untuk mengembangkan kemampuan pemahaman konsep mahasiswa. Kemampuan pemahaman konsep fisika sangat berkaitan dengan bagaimana menggunakan berbagai bahasa sains dalam pembelajaran fisika, seperti kata (lisan dan tulisan), visual (gambar, grafik, simulasi), simbol dan persamaan yang akan memungkinkan siswa mempelajari fisika melalui pengembangan kemampuan mental berpikir dengan baik. Inilah yang dinamakan multimodal representasi (Waldrip et al, 2006) ${ }^{[4]}$. Cara ini membuka peluang untuk menganalisis pemahaman konsep mahasiswa sebagai calon guru terkait materi listrik dinamis yang memungkinkan terjadinya proses pengolahan informasi secara kognitif yang lebih beragam dengan multimodal representasi.

\section{METODE PENELITIAN}

Penelitian ini merupakan penelitian deskriptif kualitatif dengan desain studi kasus. Penelitian ini dilakukan melibatkan 24 orang mahasiswa. Data diperoleh dari mahasiswa dengan memberikan tes pilihan ganda yang disertai dengan alasan dan wawancara mendalam pada 6 orang responden yang memiliki kategori tinggi, sedang dan rendah. Soal yang diberikan sebanyak 18 butir soal telah divalidasi oleh validator ahli.

Persentase skor untuk setiap representasi ditentukan dengan persamaan:

$$
X=\frac{n_{1}}{n} \times 100 \%
$$

dengan:

$X=$ Persentase skor tiap representasi

$n_{1}=$ Jumlah skor tiap representasi

$n=$ skor maksimum

Alasan yang diberikan mahasiswa akan dianalisis dan disesuaikan dengan pilihan jawaban yang diberikan. Kesesuaian antara pilihan jawaban yang benar dan alasan akan menunjukkan kemampuan representasi pada pemahaman konsep yang dimiliki mahasiswa calon guru fisika

\section{HASIL DAN PEMBAHASAN}

Hasil penelitian multimodal representasi pada mahasiswa calon guru fisika menggunakan tes pilihan ganda beralasan beserta kategorinya disajikan pada Tabel 1

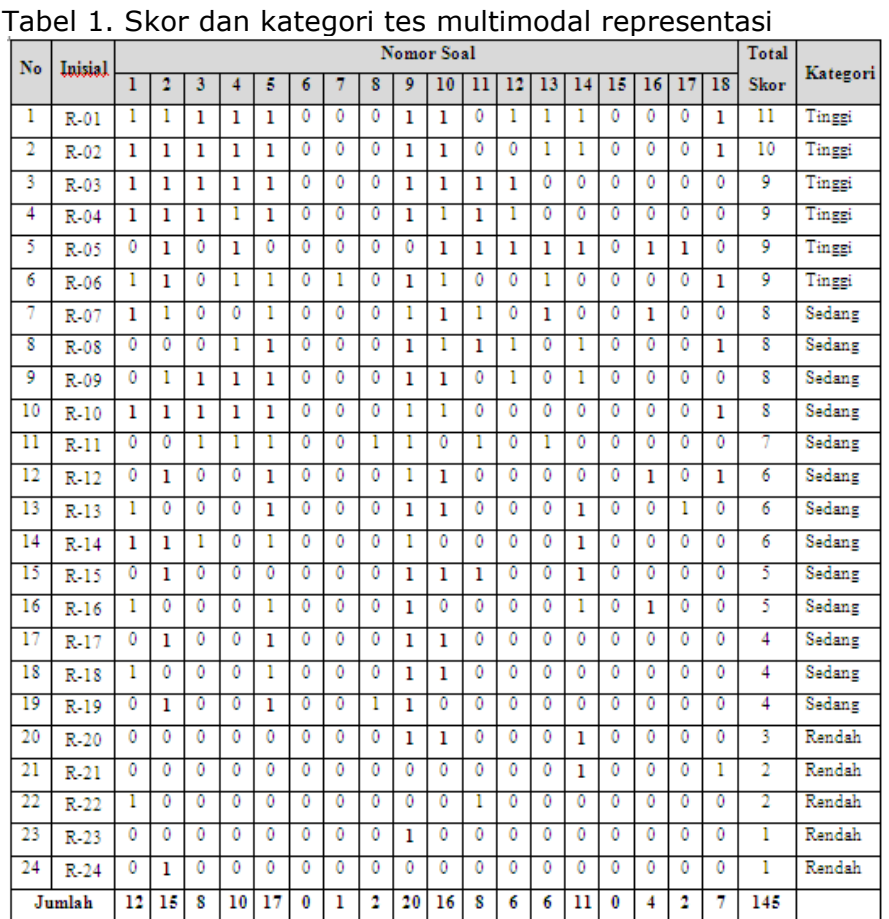

Ket: skor yang dicetak tebal: jawaban benar dengan alasan benar

Penelusuran kemampuan menelaah soal dalam berbagai representasi, pemahaman konsep, alasan pemilihan option serta dilakukan melalui wawancara berdasarkan kategori tinggi, sedang, dan rendah. Berdasarkan kategori tersebut, dipilih 2 (dua) orang dari masingmasing kategori untuk diwawancarai dengan pertimbangan dari hasil jawaban yang diberikan. Keenam responden tersebut diwawancarai tentang pemilihan option dan alasan yang diberikan.

Data yang dianalisis diambil dari tes pilihan ganda beralasan pada materi listrik 
dinamis yang terdiri dari tiga modal representasi yaitu representasi visual (terdiri dari diagram, grafik, dan gambar), representasi matematis, dan representasi verbal. Distribusi jawaban responden tiap representasi ini disajikan dalam Tabel 2.
Tabel 2. Skor dan Persentase Pemilihan Option Tiap Representasi

\begin{tabular}{|c|c|c|c|c|c|c|c|c|}
\hline \multirow[b]{3}{*}{ No } & \multirow[b]{3}{*}{ Inisial } & \multicolumn{6}{|c|}{ Multimodal Representasi } & \multirow[b]{3}{*}{ Total } \\
\hline & & \multicolumn{2}{|c|}{$\begin{array}{l}\text { Visual } \\
(5 \text { soal }) \\
\end{array}$} & \multicolumn{2}{|c|}{$\begin{array}{c}\text { Matematis } \\
\text { (5 soal) }\end{array}$} & \multicolumn{2}{|c|}{$\begin{array}{l}\text { Verbal } \\
\text { (8 soal) }\end{array}$} & \\
\hline & & $\begin{array}{c}\text { Berala } \\
\operatorname{san}\end{array}$ & $\begin{array}{c}\text { Tidak } \\
\text { Berala } \\
\operatorname{san}\end{array}$ & $\begin{array}{c}\text { Berala } \\
\operatorname{san}\end{array}$ & $\begin{array}{c}\text { Tidak } \\
\text { Berala } \\
\operatorname{san}\end{array}$ & $\begin{array}{c}\text { Berala } \\
\operatorname{san}\end{array}$ & $\begin{array}{c}\text { Tidak } \\
\text { Berala } \\
\operatorname{san}\end{array}$ & \\
\hline 1 & R-01 & 3 & 2 & 2 & 0 & 1 & 3 & 11 \\
\hline 2 & R.02 & 5 & 0 & 2 & 0 & 1 & 2 & 10 \\
\hline 3 & R.03 & 5 & 0 & 2 & 0 & 2 & 0 & 9 \\
\hline 4 & R-04 & 4 & 1 & 1 & 1 & 1 & 1 & 9 \\
\hline 5 & R-05 & 2 & 0 & 1 & 0 & 6 & 0 & 9 \\
\hline 6 & R-06 & 1 & 2 & 1 & 1 & 2 & 1 & 9 \\
\hline 7 & R-07 & 1 & 1 & 1 & 1 & 2 & 2 & 8 \\
\hline 8 & R.08 & 1 & 3 & 1 & 2 & 2 & 0 & 8 \\
\hline 9 & R-09 & 3 & 1 & 2 & 0 & 0 & 2 & 8 \\
\hline 10 & R-10 & 5 & 0 & 0 & 2 & 1 & 0 & 8 \\
\hline 11 & R-11 & 0 & 3 & 0 & 2 & 0 & 2 & 7 \\
\hline 12 & R-12 & 2 & 0 & 1 & 1 & 2 & 0 & 6 \\
\hline 13 & R-13 & 1 & 1 & 2 & 0 & 2 & 0 & 6 \\
\hline 14 & R-14 & 2 & 2 & 0 & 1 & 1 & 0 & 6 \\
\hline 15 & R-15 & 1 & 0 & 2 & 0 & 2 & 0 & 5 \\
\hline 16 & R-16 & 0 & 2 & 1 & 0 & 1 & 1 & 5 \\
\hline 17 & R-17 & 2 & 0 & 2 & 0 & 0 & 0 & 4 \\
\hline 18 & R-18 & 0 & 2 & 2 & 0 & 0 & 0 & 4 \\
\hline 19 & R-19 & 2 & 0 & 1 & 1 & 0 & 0 & 4 \\
\hline 20 & R-20 & 0 & 0 & 2 & 0 & 1 & 0 & 3 \\
\hline 21 & R-21 & 0 & 0 & 0 & 0 & 2 & 0 & 2 \\
\hline 22 & R-22 & 0 & 1 & 0 & 0 & 0 & 1 & 2 \\
\hline 23 & R-23 & 0 & 0 & 1 & 0 & 0 & 0 & 1 \\
\hline 24 & R-24 & 1 & 0 & 0 & 0 & 0 & 0 & 1 \\
\hline \multicolumn{2}{|c|}{$\begin{array}{l}\text { Jumlah Skor Tiap } \\
\text { Representasi }\end{array}$} & 41 & 21 & 27 & 12 & 28 & 16 & 145 \\
\hline \multicolumn{2}{|c|}{$\begin{array}{c}\text { Skor Maksimum } \\
\text { Tiap Representasi }\end{array}$} & \multicolumn{2}{|c|}{120} & \multicolumn{2}{|c|}{120} & \multicolumn{2}{|c|}{192} & 432 \\
\hline \multicolumn{2}{|c|}{$\begin{array}{c}\text { Persentase Skor } \\
\text { Tiap Representasi } \\
(\%)\end{array}$} & 34,17 & 17,50 & 22,50 & 10,00 & 14,58 & 8,33 & \\
\hline
\end{tabular}

Hasil dari repsesentasi mahasiswa dengan tiga modal representasi dapat disederhanakan pada Gambar 1

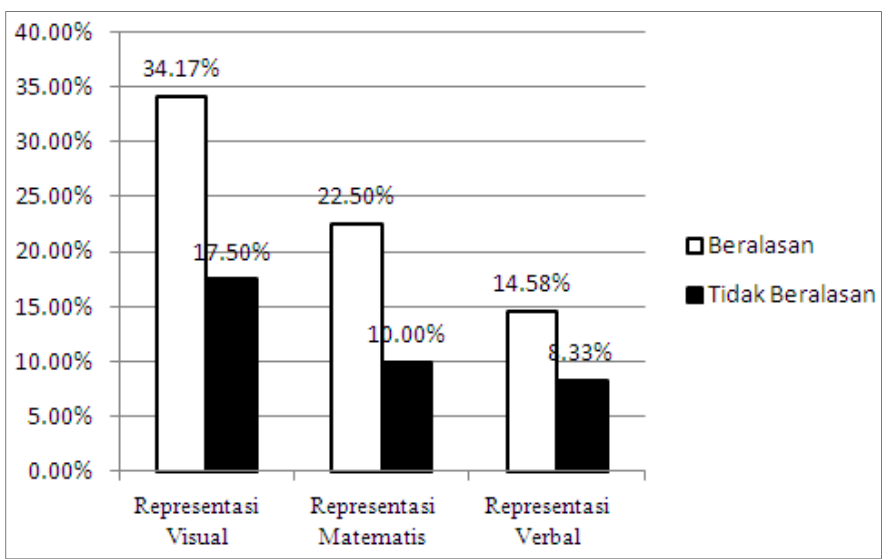

Gambar 1. Diagram Persentase Pemilihan Jawaban Tiap Representasi

\section{1) Representasi Visual}

Soal yang direpresentasikan dalam bentuk visual terdapat 5 butir soal yaitu nomor 1 sampai nomor 5. Soal nomor 1 dan 2 direpresentasikan dalam bentuk diagram, soal nomor 3 dan 4 direpresentasikan dalam bentuk grafik, dan soal nomor 5 direpresentasikan dalam bentuk gambar.

Persentase skor rata-rata yang diperoleh mahasiswa untuk representasi visual dengan jawaban yang disertai alasan sebesar 34,17\%. Berikut adalah kutipan alasan dan wawancara tiap soal.

a. Soal nomor 1

Soal ini direpresentasikan dalam bentuk diagram. Kebanyakan mahasiswa memiliki pemahaman bahwa lampu yang dekat sumber aruslah yang memiliki kuat arus atau nyala lampu yang paling terang. Berikut kutipan alasannya

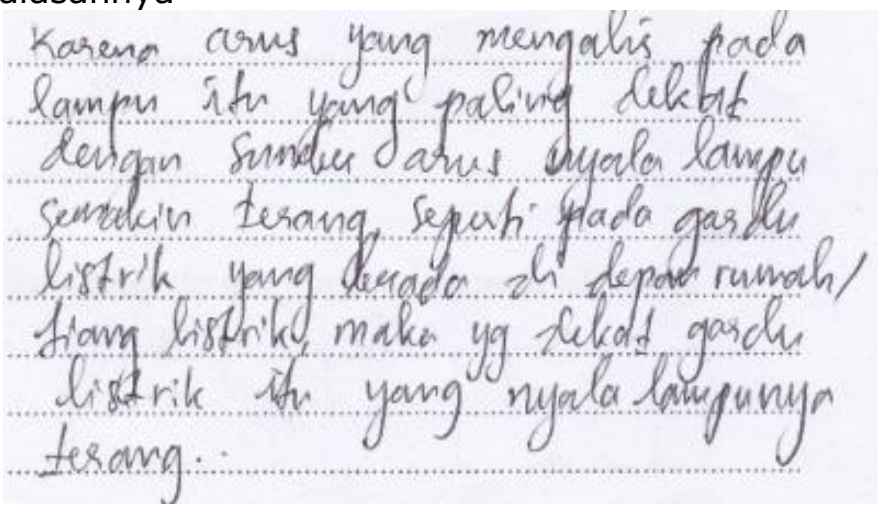

Gambar 2. Kutipan Alasan R-13 untuk Soal Nomor 1

Responden hanya sebatas memahami bahwa lampu paling dekat dengan sumber arus yang paling terang, berikut kutipan wawancaranya 
Peneliti : Alasan anda pada nomor 1 mengatakan bahwa lampu yang paling dekat dengan sumber arus yang paling terang sehingga anda memilih option $D$ dimana arus dari $B$ lebih dekat ke $C$ dibanding ke $D$ dan E. apa perbedaan arus yang mengalir ke dari $B$ ke $C$ dibanding dari B ke D?

R-13 : Dari gambarnya saja sudah jelas, jarak dari $B$ ke C lebih dekat dibanding jarak dari $B$ ke $D$.

Peneliti : Mengapa anda mengatakan lampu yang paling terang adalah lampu yang paling dekat dengan sumber arus?

R-13 : Guru saya di SMA pernah menjelaskan hal ini. Contohnya sebuah gardu di depan rumah. Nyala lampu di rumah tetangga akan lebih terang dibanding dengan lampu di rumah yang jauh dari gardu.

Peneliti : Apakah anda memahami prinsip rangkaian seri dan paralel di sini?

R-13 : Paham.

Peneliti : Bisa anda menunjukkan rangkaian mana yang merupakan rangkaian seri di sini?

R-13 : Rangkaian serinya dari $A, B, D$, dan E.

Peneliti : Bagaimana dengan C?

R-13 : C disusun paralel dengan $B$ dan $E$

Peneliti : Apakah anda mudah memahami dengan menggunakan diagram ini?

$\mathrm{R}-13$ : Iya.

Mereka tidak memahami bahwa nyala lampu lebih dekat dengan sumber arus lebih terang karena belum ada percabangan arus. Responden mengatakan bahwa mereka mudah menganalisis diagram pada soal nomor 1 .

\section{b. Soal nomor 2}

Pemahaman responden tentang beda potensial untuk rangkaian seri lebih rendah dibanding paralel. Berikut salah satu kutipan alasan responden

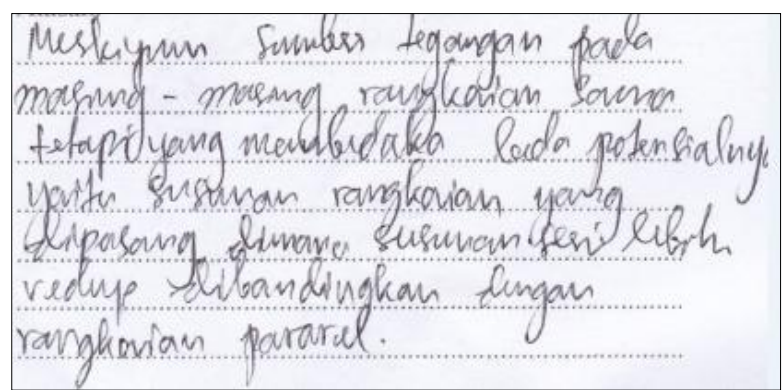

Gambar 3. Kutipan Alasan R-13 untuk Soal Nomor 2

Pemahaman responden ini saat menjawab soal dan ketika diwawancarai berbeda. Berikut kutipan wawacara dengan responden

Peneliti : Pada soal nomor 2 ini, rangkaian 1, 2, dan 3 termasuk rangkaian apa?

R-13 : Rangkaian 1 paralel, rangkaian 2 seri, rangkaian 3 juga seri.

Peneliti : Jawaban anda pada soal nomor 2 ini adalah option C. Mengapa?

R-13 : (diam)

Peneliti : Tadi anda mengatakan jika disusun paralel, tegangannya akan sama. Jika kita perhatikan rangkaian ini, berapa total tegangan tiap rangkaian jika dimisalkan nilai tiap tegangan 6V?

R-13 : Rangkaian 1 itu $V_{1}=V_{2}=6 \mathrm{~V}$. Rangkaian 2 sebesar 12V, rangkaian 3 cuma 6V.

Peneliti : Tapi mengapa di option anda pilihan anda, anda memilih option C dimana beda potensial rangkaian 2 dan 3 sama?

R-13 : Karena awalnya saya melihat susunannya sama-sama seri.

Peneliti : Jika dibandingkan dengan soal nomor 14, mana yang lebih mudah anda pahami?

R-13 : Nomor 2 ini, ada gambarnya

Responden ini pada awalnya memahami bahwa besar beda potensial hanya tergantung pada susunan rangkaiannya. Ketika diwawancarai responden memahami bahwa besar beda potensial tidak hanya bergantung pada susunan rangkaian tapi juga jumlah sumber tegangan yang dipasang. Responden mengaku lebih mudah memahami representai visualnya dibanding dengan verbal.

c. Soal nomor 3 
Soal ini direpresentasikan dalam bentuk grafik. Berikut salah satu kutipan alasan responden

karena hubungan antara hambatan (R) gan panjarg kawat (l) ketika. Di kaikkan zengan Persamaan maka. hambakannya borbanging terbalik. osngon kanjang kawak schingga grafik yang tepat asalah bogian D.

Gambar 4. Kutipan Alasan R-13 untuk Soal Nomor 3

Hampir semua responden memberikan alasan yang benar tetapi pilihan jawabannya salah. Berikut kutipan wawancara dengan responden

Peneliti : Bagaimana persamaan yang menyatakan hubungan antara panjang kawat dengan hambatan kawat?

R-21 : $R=\rho \frac{l}{A}$. Hambatan berbanding lurus dengan panjang kawat dan berbanding terbalik dengan luas penampang.

Peneliti : Mengapa anda memilih option D?

R-21 : Salah lalu itu kak. Saya lupa rumusnya lalu. Baru saya pikir karena dipotong melintang makanya saya pilih yang garis melintang ini. Seharusnya jawabannya $A$.

Peneliti : Apa bedanya dengan option $B$ ?

R-21 : Bagian $B$ itu terbalik, arahnya ke bawah. Kalau bagian A arahnya ke atas. Kan kalau semakin besar I-nya semakin besar pula R-nya jadi grafiknya naik.

Peneliti : Tapi soalnya ini mengatakan kawatnya dipotong sehingga I-nya semakin kecil.

R-21 : Aduhh, saya bingung kak. Tapi saya tetap yakin di A kak.

Responden ini kesulitan menganalisis grafik. Pilihan jawabannya pun sudah berbeda ketika diwawancarai dimana pada awalnya memilih grafik yang melintang menjadi grafik yang naik. Responden ini memahami hubungan panjang kawat dengan hambatannya tetapi pemilihan optionnya belum tepat.

d. Soal nomor 4
Soal ini direpresentasikan dalam bentuk gambar. Responden tidak memahamami cara memasangan alat ukur pada rangkaian. Berikut kutipan alasannya

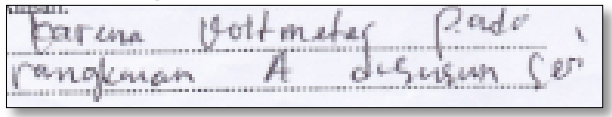

Gambar 5. Kutipan Alasan R-13 untuk Soal Nomor 4

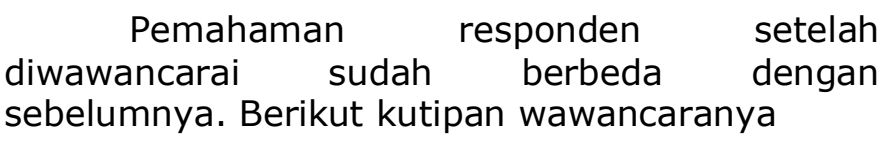

Peneliti : Apakah amperemeter dirangkai seri atau paralel?

R-20 : Seri kak. Saya pernah praktikum ini kak

Peneliti : Di sini anda memilih option $A, R_{L}$ dengan A ini dirangkai apa?

R-20 : Paralel.

Peneliti : Bagaimana dengan $R_{L}$ dengan $V$ ?

R-20 : Paralel.

Peneliti : Jadi mana yang benar?

R-20 : Lalu itu waktu saya kerja soal ini saya lupa, arus disusun seri atau paralel. Tapi sebenarnya sudah dijelaskan dan saya ingat sekarang. Yang benar itu sebenarnya option B

R-20 : Apakah anda memahami soal ini jika direpresentasikan dalam bentuk gambar?

Peneliti : Iya, lebih mudah dipahami.

Terdapat beberapa responden yang memiliki pemahaman berbeda saat menjawab soal dan ketika diwawancarai. Hal ini karena mereka kurang teliti pada saat menjawab soal. Berdasarkan hasil pemilahan alasan dan wawancara dengan responden, terlihat bahwa responden lebih memahami representasi visual ini. Mereka memahami bahwa amperemeter dirangkai seri dan voltmeter dirangkai paralel hanya saja mereka sudah tidak memahami ketika dalam rangkaian terdapat rangkaian gabungan (rangkaian seri ke paralel). Pemahaman responden masih tergolong rendah. Beberapa dari mereka yang mengaku lebih memahami soal dalam representasi gambar karena mereka sudah pernah mencoba merangkai dan ketika direprestasikan dalam bentuk verbal seperti pada soal nomor 10, mereka mulai kesulitan dalam menganalisanya. 


\section{e. Soal nomor 5}

Soal nomor 5 direpresentasikan dalam bentuk gambar. Hanya terdapat dua responden yang memberi jawaban benar dan disertai alasan yang tepat, selain dari itu ada yang menjawab benar tetapi tidak disertai alasan dan juga tidak menjawab. Berikut adalah kutipan wawancara dengan responden yang tidak dapat menjawab
Peneliti : Pada soal nomor 5 anda memilih option $D$, bagaimana cara anda menghitung sehingga mendapatkan jawabannya?
R-07 : (bingung)

Peneliti : Pada gambar ini, mana yang disebut skala penunjukan jarum?

R-07 : Yang ditunjuk panah.

Peneliti : Skala maksimum yang mana?

R-07 : (diam)

Peneliti : Apakah anda sudah pernah mencoba alat ukur ini?

R-07 : Tidak. Hanya pakai yang digital.

Peneliti : Apakah di sekolah anda pernah diajarkan?

R-07 : Tidak.

Peneliti : Apa yang anda pahami tentang batas ukur?

R-07 : Batas ukur itu kemampuan maksimal yang di ukur. Ketika hanya 1 A, berarti tidak bisa lagi mengukur di atas $1 A$.

R-07 belum mampu dalam representasi ini karena pada dasarnya belum mempelajari materi alat ukur analog. Kebanyakan dari responden hanya menebak (memperkirakan). Ada yang mengatakan bahwa mereka belum pernah melihat alat ukur analog tersebut dan mengaku belum pernah diajarkan sehingga mereka tidak memahami jika direpresentasikan dalam bentuk gambar. Mereka hanya sebatas memahami bagian-bagian pada alat ukur tersebut tetapi tidak tahu cara menggunakan dan menghitungnya.

\section{2) Representasi Matematis}

Representasi ini terdiri dari 5 butir soal. Persentase skor rata-rata yang diperoleh mahasiswa untuk representasi matematis dengan jawaban yang disertai alasan sebesar 22,50\%. Berikut adalah kutipan alasan dan wawancara tiap soal. a. Soal nomor 6

Soal nomor 6 direpresentasikan dalam bentuk matematis Namun, tidak ada seorang pun yang menjawab soal nomor 6 dengan benar. Berikut salah satu kutipan alasan responden

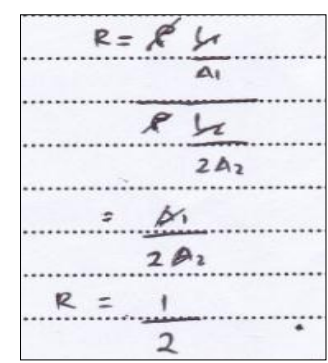

Gambar 6. Kutipan Alasan R-01 untuk Soal Nomor 6

Peneliti : Apa yang anda pahami pada soal nomor 6 ini?

R-01 : Di sini diketahui hambatan pertama dan ditanyakan hambatan kedua. Makanya saya memakai persamaan $R=\rho \frac{l}{A}$ untuk menyelesaikannya.

Peneliti : Apa anda yakin memilih 1/2R?

R-01 : Sebenarnya $2 R$ jawabannya kak. Cuma saya bingung menggunakan persamaan ini. Disini $\rho$ dengan $l$ habis, jadi sisa $\frac{1}{A}$. Jadi saya langsung bagi saja.

Pemahaman konsep untuk hambatan kawat dipahami oleh responden ini, hanya saja ketika direpresentasikan dalam bentuk perbandingan, responden sulit menganalisnya.

\section{b. Soal nomor 7}

Tidak ada yang memberi alasan pada soal ini. Soal ini terkait dengan energi listrik dan direpresentasikan dalam bentuk mencari persamaan dari representasi verbal yang diberikan. Berikut kutipan wawancara dengan responden

Peneliti : Apa yang anda pahami pada soal nomor 7 ini?

R-01 : Saya tidak tahu kak.

Peneliti : Lalu mengapa anda bisa memilih option A?

R-01 : Asal silang itu kak.

Peneliti : Apakah anda memahami konsep ini dalam bentuk matematis/perhitungan?

R-01 : Tidak, baru melihat rumusnya saja sudah ribet. 
Responden ini tidak memahami konsep dalam respresentasi matematis dan menganggap itu rumit dan membingungkan.

\section{c. Soal nomor 8}

Tidak ada dari responden yang diwawancarai yang dapat menjawab soal nomor 8. Berikut kutipan wawancara dengan responden Peneliti : Mengapa anda tidak menjawab soal nomor 8 ini?

R-05 : (diam)

Peneliti : Apa yang anda pahami pada soal nomor 8 ini?

R-05 : $R_{1}$ dan $R_{2}$ ini seri. $R_{3}$ dan $R_{4}$ seri dan paralel dengan $R_{5}$.

Peneliti : Anda memahami rangkaiannnya, tapi mengapa anda tidak menjawab?

R-05: Membosankan. Butuh waktu yang lama untuk mencari ini kak. Kalau kata-kata seperti nomor 11, tidak perlu menghitung. Jadi hanya butuh ketelitian kak. Perhitungan membuat saya malas.

Peneliti : Soal mana yang lebih anda suka analisis? Apakah gambar, kata-kata atau matematik?

R-05 : Saya suka menganalisa kata-kata.

Responden memahami susunan rangkaian pada gambar hanya saja menggangap bahwa representasi matematis ini membosankan sehingga responden tidak menyelesaikannya. Terdapat beberapa responden yang tidak memahami materi atau konsep ini sekalipun direpresentasikan dalam bentuk lain seperti verbal.

\section{d. Soal nomor 9}

Soal nomor 9 ini menanyakan tentang cara membaca alat ukur dan melihat hasil pengukurannya. Dimana cara menentukan besar arus adalah dengan membagi nilai skala penunjukan jarum dengan skala maksimumnya kemudian dikalikan dengan batas ukur. Berikut salah satu kutipan alasan responden

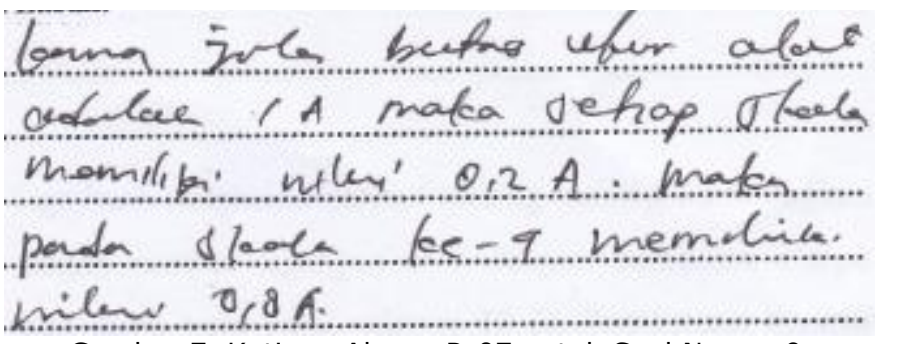

Gambar 7. Kutipan Alasan R-07 untuk Soal Nomor 9

Responden ini menggunakan cara yang berbeda dalam menyelesaikan soal nomor 9 ini. Berikut pernyataan responden dalam wawancara

Peneliti : Pada soal ini anda memilih option D, bagaimana cara anda menghitung sehingga mendapatkan jawabannya?

R-07 : (bingung)

Peneliti : Pada gambar ini, mana yang disebut skala penunjukan jarum?

R-07 : Yang ditunjuk panah.

Peneliti : Skala maksimum yang mana?

R-07 : (diam)

Peneliti : Apakah anda sudah pernah mencoba alat ukur analog?

R-07 : Tidak. Hanya pakai yang digital.

Peneliti : Apakah di sekolah anda pernah diajarkan?

R-07 : Tidak.

Peneliti : Tapi, anda bisa menjawabnya soal ini dengan benar. Mengapa?

R-07 : Karena yang ini jelas kak. Batas ukurnya 1 , skala maksimumnya 5. 5 jarum penunjukan skala. Jadi 1 A itu dibagi 5 bagian. Jadi setiap penunjukan-penunjukan skala itu 0,2 . Pada skala ke-4 menunjukkan $0,8 \mathrm{~A}$.

Peneliti : Apa yang anda pahami tentang batas ukur?

R-07 : Batas ukur itu kemampuan maksimal yang di ukur. Ketika hanya 1 A, berarti tidak bisa lagi mengukur di atas $1 A$.

Responden ini tidak menggunakan cara atau persamaan yang biasa digunakan dalam menhitung besar arus tetapi menggunakan konsep dasar dalam pengukuran dan responden ini mampu menjawab dengan tepat representasi matematis ini. Akan tetapi, responden hanya mampu menggunakan cara ini pada soal nomor 9 tetapi tidak pada soal nomor 5 dimana memiliki 
konsep sama tapi direpresentasikan dalam bentuk visual.

e. Soal nomor 10

Sebagian besar responden memilih jawaban yang benar. Berikut kutipan alasannya

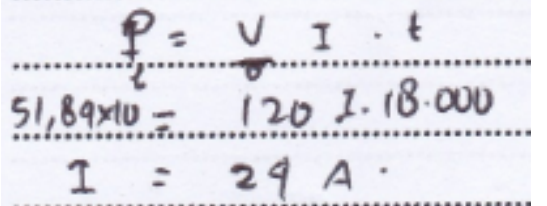

Gambar 8. Kutipan Alasan R-01 untuk Soal Nomor 10

Responden ini keliru dalam menggunakan persamaan, berikut alasannya ketika diwawancarai

Peneliti : Pada soal nomor 10 anda menggunakan persamaan $\mathrm{P}=\mathrm{V}$. I. t. mengapa anda menggunakan persamaan ini?

R-01 : Kan disini diketahui energinya. Dari diketahuinya saja, makanya saya pakai rumus ini. Dan seingat saya rumusnya seperti ini.

Peneliti : P ini apa?

R-01 : Daya

Peneliti : Lalu anda mengatakan tadi yang diketahui adalah energinya. Mengapa anda menggunakan daya?

R-01 : Saya bingung juga sih pakai rumus yang mana dan saya cuma ingat rumus ini.

Peneliti : Apakah tidak ada persamaan lain yang bisa digunakan?

R-01 : Saya tidak tahu lagi kak.

Peneliti : Apakah anda memahami jika soal ini dibuat dalam bentuk seperti ini (perhitungan)?

R-01 : Tergantung rumusnya ribet atau tidak.

Representasi ini mampu diselesaikan oleh R-01 hanya saja penggunaan rumusnya belum tepat. Responden ini mengaku bahwa ia mampu menyelesaiakan

representasi-representasi matematis apabila persamaannya tidak rumit. Banyaknya persamaan-persamaan maupun perhitungan membuat mereka sulit mengerjakan seperti menentukan besar arus pada tiap hambatan dalam rangkaian campuran dan energi listrik.

\section{3) Representasi Verbal}

Persentase skor rata-rata yang diperoleh mahasiswa untuk representasi verbal dengan jawaban yang disertai alasan sebesar $14,58 \%$ dengan jumlah soal 8 butir.

a. Soal nomor 11

Hanya 1 responden yang menjawab benar dan dengan alasan yang tepat selain dari itu salah. Berikut adalah kutipan alasan responden yang menjawab salah

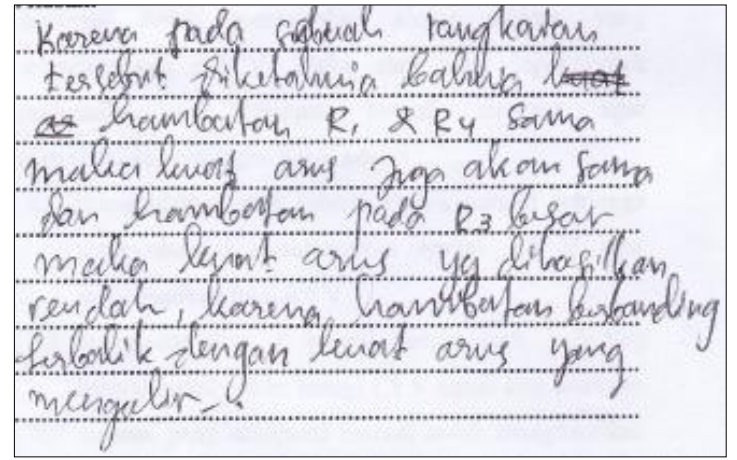

Gambar 9. Kutipan Alasan R-13 untuk Soal Nomor 11

Responden tidak memahami pengaruh susunan rangkaian terhadap hambatan. Berikut kutipan wawancaranya

Peneliti : Pada soal nomor 11 ini anda mengatakan $R_{1}$ dan $R_{4}$ memiliki kuat arus yang sama dan $R_{3}$ memiliki kuat arus paling rendah. Mengapa?

R-13 : Karena $R_{1}$ dan $R_{4}$ ini hambatannya sama yaitu 2 ohm, sedangkan $R_{3}$ ini hambatannya paling tinggi sehingga kuat arusnya paling rendah.

Peneliti : Apakah ada pengaruh susunan rangkaian di sini?

R-13 : Tidak berpengaruh kak.

Peneliti : $\mathrm{R}$ apa saja yang dirangkai seri dan paralel disini?

R-13: $R_{1}, R_{2}$, dan $R_{3}$ ini disusun paralel kemudian seri dengan $R_{4}$.

Soal nomor,11 terkait dengan menentukan besar kuat arus dalam suatu rangkaian. Soal ini diselesaikan dengan cara menentukan hambatan total dalam rangkaian terlebih dahulu. Pada soal ini hanya terdapat dua responden yang mampu menjawab dengan alasan yang tepat yaitu karena adanya percabangan jadi arus pada $R_{1}$ dan $R_{4}$ berbeda sekalipun hambatannya sama. Selain dari itu 
mereka memahami bahwa tidak ada pengaruh susunan rangkaian terhadap kuat arus suatu hambatan seperti kutipan alasan di atas dan yang ditunjukkan pada hasil wawancara dengan R-13.

\section{b. Soal nomor 12}

Responden belum memahami besar beda potensial ketika dirangkai seri maupun paralel. Berikut kutipan alasannya

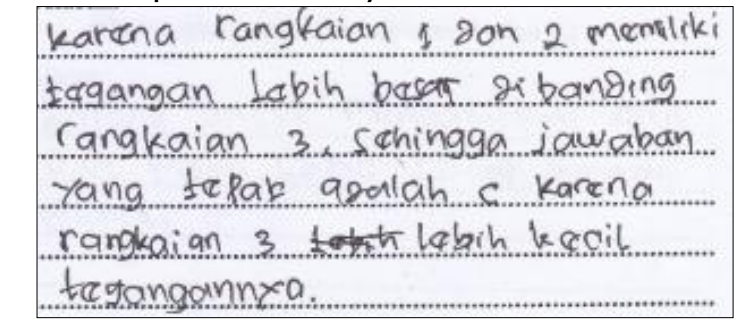

Gambar 10. Kutipan Alasan R-21 untuk Soal Nomor 12

Setelah diwawancarai ternyata pemahaman mereka sudah berbeda. Berikut kutipan wawancaranya

Peneliti : Pada gambar ini menurut anda rangkaian 1,2, dan 3 termasuk rangkaian apa?

R-21 : Rangkaian 1 paralel, rangkaian 2 seri, rangkaian 3 juga seri.

Peneliti : Soal ini berkaitan dengan nomor 2. Soal nomor 2 membahas tegangan sedangkan disini membahas kuat arus. Mengapa anda bisa mengatakan bahwa rangkaian 3 memiliki kuat arus yang paling rendah?

R-21 : Terbalik lagi kak. Sebenarnya yang paling besar kuat arusnya adalah rangkaian 2.

Peneliti : Mengapa?

R-21 : Ini kan ada persamaan $I=\frac{V}{R}$. Semakin besar arusnya, semakin besar pula tegangannya. Arus berbanding lurus dengan tegangan.

Peneliti : Jadi, jawaban mana yang benar?

R-21 : Option E, rangkaian 2 memiliki kuat arus paling tinggi.

Representasi verbal ini dipahami oleh responden. Responden ini memahami jenis rangkaian dan hubungan tegangan dengan kuat arus ketika diwawancarai, walaupun pilihan jawabannya berbeda dengan yang sebelumnya. Sebelumnya responden mengatakan bahawa ketika sumber tegangan dirangkai seri, arus yang mengalir akan sama tetapi ketika dirangkai paralel tegangannya yang tetap sama sekalipun terdiri dari beberapa sumber tegangan.

c. Soal nomor 13

Representasi matematis untuk perbandingan dua buah hambatan hanya dipahami oleh satu responden. Berikut kutipan alasannya

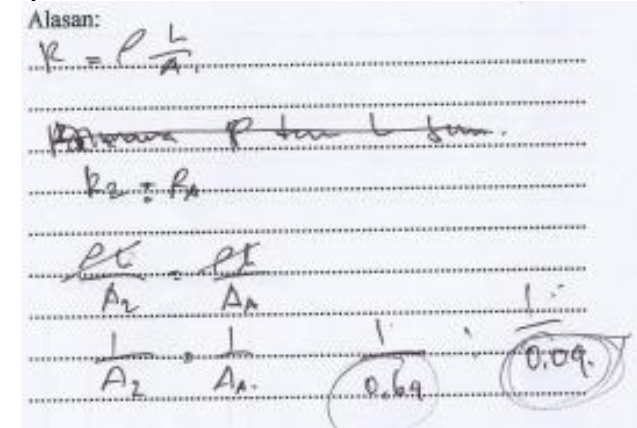

Gambar 11. Kutipan Alasan R-07 untuk Soal Nomor 13

Berikut kutipan wawancara dengan responden yang menjawab benar

Peneliti : Apa anda tahu persamaan menghitung hambatan kawat?

R-07 : $R=\rho \frac{l}{A}$

Peneliti : Mengapa anda bisa memilih option $\mathrm{E}$

R-07 : Disini jelas luas penampangnya. $R_{1}$ : $\quad R_{2}$ jadi $\frac{1}{0,64}: \frac{1}{0,04}$. Pasti perbandingannya 1:16.

Peneliti : Mengapa anda tidak memilih B dimana hambatan kawat Zaki 16 lebih besar?

R-07 : Karena luas penampang Zaki lebih kecil sehingga hambatannya lebih besar.

Konsep hambatan dan perbandingannya dengan hambatan lain mampu dianalisis oleh responden ini dalam representasi verbal. selain dari itu menjawab salah. Pemahaman responden tentang pengaruh diameter kawat terhadap hambatannya masih tergolong rendah karena mereka kurang memahami tentang perbandingan. Beberapa responden sudah memahami bahwa diameter yang besar akan membuat hambatannya kecil akan tetapi mereka tidak memahami verbal maupun matematis seperti pada soal nomor 6 


\section{d. Soal nomor 14}

Beberapa responden memilih jawaban yang benar walaupun sebenarnya mereka tidak memahami. Berikut kutipan alasannya

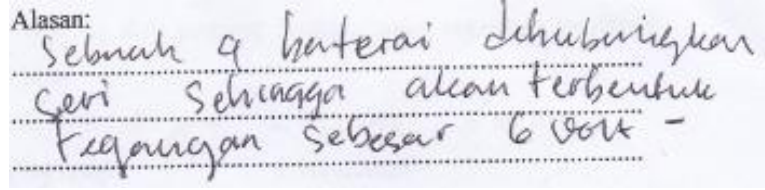

Gambar 12. Kutipan Alasan R-20 untuk Soal Nomor 14

Pernyataan responden memberi alasan seperti di atas dapat dilihat pada kutipan wawancara berikut

Peneliti : Di sini anda memilih B. Mengapa?

R-20 : Ini saya tidak dapat dapat jawabannya.

Peneliti : Lalu apa alasan anda memilih option $\mathrm{B}$ ?

R-20 : Ini, kan saya pernah baca di buku, katanya kalau untuk menjalankan baterai biar lampu bisa menyala, misalnya dia membutuhkan tegangan $6 \mathrm{~V}$ dia harus disusun secara seri.

Peneliti : Lalu mengapa anda mengatakan tadi, arus pada rangkaian seri itu sama.

R-20 : Pokoknya pas saya jawab lalu itu, saya lupa. Kalau tegangan sama itu disusun paralel atau seri. Makanya antara menghubungkan 4 baterai secara paralel atau menghubungkan 4 baterai secara seri. Saya lupa juga makanya saya pilih B saja.

Peneliti : Anda yakin?

R-20 : Ehh, terbalik kak. Kalau paralel tegangannya yang sama, kalau seri arusnya yang sama.

Peneliti : Jika soal ini dibandingkan dengan soal nomor 2 atau 12, soal mana yang lebih anda pahami?

R-20 : Sebenarnya tidak ada yang saya paham kak.

Peneliti : Yang lebih mendekati paham yang mana?

R-20 : Sebenarnya ini (soal nomor 14) yang saya pernah baca cuma saya lupa.

Responden ini pada dasarnya tidak memahami konsep sehingga sekalipun direpresentasikan dalam bentuk yang berbeda.
Dari wawancara ini terlihat bahwa responden sulit menganalisa soal ini karena kesulitan akan konsep yang tepat untuk menjawabnya.

e. Soal nomor 15

Tidak ada yang mampu menjawab soal ini. berikut kutipan wawancara dengan responden Peneliti : Mengapa anda tidak menjawab soal nomor 15 ini?

R-07 : Saya tidak paham.

Responden yang lain tidak memahami perintah soalnya.

Peneliti : Mengapa anda tidak menjawab soal nomor 15 ini?

R-13 : Saya bingung, ini soal mau diapakan.

f. Soal nomor 16

Responden memahami bahwa ketika rangkaian disusun seri, arusnya akan sama besar. Berikut kutipan alasannya

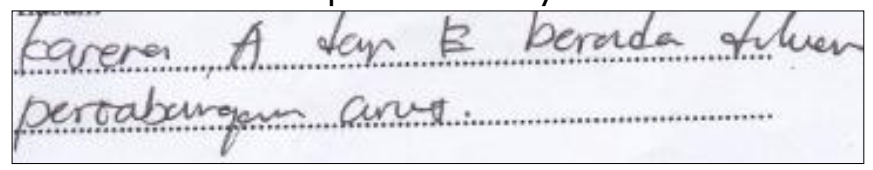

Gambar 13. Kutipan Alasan R-13 untuk Soal Nomor 16

Berikut adalah kutipan wawancara dengan responden ini

Peneliti : Pada soal nomor 16 ini, lampu apa saja yang dirangkai seri maupun paralel?

R-07 : Arus dari $A$ terbagi ke $B$ dan $D$. $B$ dengan $C$ ini seri. $D$ paralel tapi bingung.

Peneliti : Mengapa anda memilih option B, dimana lampu A dan $E$ yang menyala paling terang?

R-07 : Karena di sini betul-betul arus total yang masuk. Arus yang masuk di $A$ mengalir ke $B, C$ dan $E$ di mana arusnya lebih kecil. Tetapi arus yang keluar dari percabangan $C, D$, dan $E$ terkumpul lagi di $E$.

Peneliti : Apakah anda mudah memahami soal yang disajikan seperti ini?

R-07 : Mudah, apalagi ini cuma disuruh lihat mana yang paling terang.

Responden memahami konsep besar arus dalam suatu rangkaian jika direpresentasikan dalam bentuk verbal. 
g. Soal nomor 17

Responden

memahami

bahwa

amperemeter dipasang secara seri. Berikut kutipan alasannya

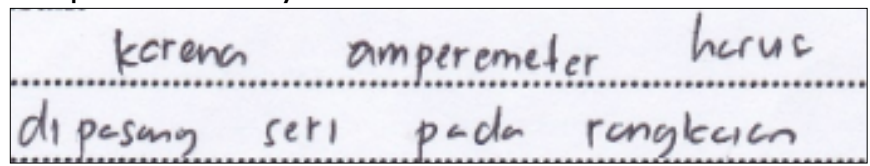

Gambar 14. Kutipan Alasan R-13 untuk Soal Nomor 17 Alasan responden sudah tepat akan tetapi tidak memahami ketika amparemeter diletakkan dalam rangkaian campuran

Peneliti : Alasan anda pada soal nomor 4 dan 17 ini mengatakan amperemeter dirangkai seri dengan hambatan. Jika kita melihat soal nomor 17 , mengapa anda mengatakan hanya alat ukur nomor 1 yang tepat untuk pemasangan amperemeter?

R-01 : Kalau saya melihat gambarnya memang hanya nomor 1 ini yang cocok untuk amperemeter.

Peneliti : Lalu bagaimana dengan alat ukur nomor 2?

R-01 : Kalau yang di dalam ini rangkaiannya menjadi paralel. Jika amperemeter dipasang di nomor 2 ini, otomatis jadi paralel karena $R_{2}$ dengan $R_{3}$ ini paralel. Nomor 1 ini memang sudah jelas seri.

Peneliti : Seandainya alat ukur nomor 3 dan $\mathrm{R}_{3}$ ini dihilangkan apakah $\mathrm{R}_{2}$ dan alat ukur nomor 2 ini tersusun seri atau paralel?

R-01 : Paralel, karena tetap garisnya masuk begini(percabangan)

Peneliti : Dari kedua soal ini (soal nomor 4 dan 17), mana yang lebih mudah anda pahami?

R-01 : Nomor 4. Lebih mudah saya melihat gambar dibanding kata-kata ini.

Kemampuan representasi verbal

responden ini dalam memahami konsep penyusunan alat ukur masih kurang dimana belum memahami ketika alat ukur dipasang pada rangkaian campuran (seri-paralel).

\section{h. Soal nomor 18}

Responden mengatakan bahwa hambatan tidak berngaruh pada tegangan. Alasan responden dapat dilihat pada gambar berikut

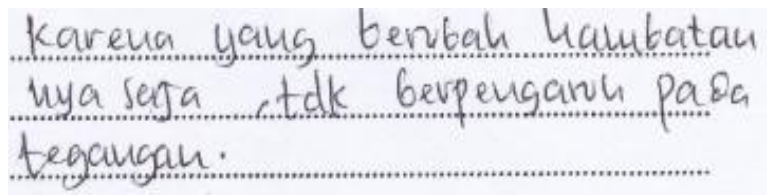

Gambar 15. Kutipan Alasan R-13 untuk Soal Nomor 18

Peneliti : Di soal nomor 18 ini anda menjawab tetap karena tidak berpengaruh terhadap tengangan. Mengapa demikian?

R-05 : Pemahaman saya di sini kawatnya itu sejenis. Misalnya sama-sama tembaga, kemudian hanya bertambah panjang, maka tegangan listrik tetap. Yang bertambah di sini adalah hambatannya.

Peneliti : Bagaimana hubungan antara arus, tegangan dan hambatan di sini?

R-05: Kalau mengacu pada hukum ohm, semakin besar tegangannya maka semakin besar arusnya. Semakin besar arusnya maka semakin kecil hambatannya. arus dengan hambatan berbanding terbalik.

Peneliti : Jika dibandingkan dengan soal nomor 3, mana yang lebih mudah anda pahami?

R-05 : Saya lebih ke 18. Konsepnya ini sama cuma taraf kesulitannya menurut saya beda. Yang nomor 3 ini menganalisa grafik

Apabila panjang kawatnya kecil maka hambatannya pun kecil karena hambatan sebanding dengan panjang kawatnya. Dengan demikian jawaban yang tepat untuk soal nomor 18 adalah tegangan listrik menurun karena hambatannya menjadi besar ditandai dengan panjang kawat yang bertambah.

Responden memilih option tetap dengan alasan panjang kawat tidak berpengaruh pada tegangannya melainkan hanya berpengaruh pada hambatannya. Responden hanya sebatas memahami hubungan panjang kawat dengan hambatannya tetapi tidak berpengaruh pada tegangannya, sehingga pemahaman responden untuk representasi verbal cukup rendah dimana responden menganggap bahwa verbal membutuhkan analisis yang tinggi. Mereka cukup memahami ketika verbalnya disertai dengan gambar. 
Responden mengatakan bahwa melalui multimodal representasi ini, memudahkan mereka dalam memahami konsep. Penelitian ini relevan dengan penelitian yang dilakukan oleh Waldrip yang menemukan bahwa dalam penyelesaian tugas dengan berbagai modal dapat memperluas pemahaman siswa, mampu mengkomunikasikan ide-ide, dan meningkatkan pengetahuan siswa terkait dengan materi yang dipelajari.

\section{BAB IV. KESIMPULAN DAN SARAN}

Berdasarkan uraian di atas maka dapat disimpulkan bahwa representasi visual lebih dipahami oleh mahasiswa dibanding dua representasi yang lain. Mereka lebih memahami khususnya gambar dan diagram, akan tetapi pemahaman grafiknya masih kurang. Mereka mengatakan bahwa dengan penjelasan yang diberikan dalam bentuk visual membantu mereka dalam menganalisis soal dengan mudah.

Pemahaman mahasiswa pada representasi matematis cukup rendah dikarenakan banyaknya persamaan-persamaan maupun perhitungan membuat mereka sulit mengerjakannya.

Pemahaman mahasiswa untuk representasi verbal paling rendah dimana mereka menganggap bahwa representasi verbal membutuhkan analisis yang tinggi.

Berdasarkan kesimpulan, diharapkan dapat dipertimbangkan bahwa pengajar fisika perlu untuk menggunakan multimodal representasi.

\section{DAFTAR PUSTAKA}

[1] Menteri Pendidikan Nasional. (2006). Peraturan Menteri Pendidikan Nasional No.22 Tahun 2006 tentang Standar Isi untuk Satuan Pendidikan Dasar dan Menengah. [Online]. Tersedia: http://bsnpindonesia.org/id/wp-

content/uploads/isi/Permen_22_2006.html Oktober 2015]

[2] Waldrip, B. (waldrip@usq.edu.au). (2014, 20, November). Using multi-modal representations to enhance primary science learning. E-mail kepada Adolfina Galla (adolfinagalla39@ymail.com)

[3] Pertiwi, R.S. (2013). Analisis Kemampuan Representasi Siswa dalam Menyelesaikan Masalah Tes Uraian Terstruktur dan Tes Uraian Bebas pada Materi
Kelistrikan. Skripsi pada UPI Bandung.

[4] Waldrip, B., Prain,V., dan Carolan, J. (2006). Learning Junior Secondary Science through Multi-Modal Representations. Electronic Journal of Science Education. 11 (1), 86-105. 